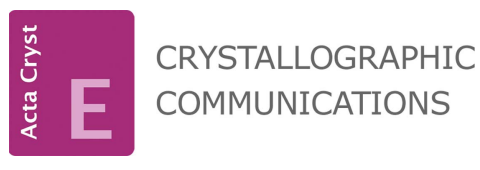

ISSN 2056-9890

Received 20 February 2017

Accepted 23 May 2017

Edited by W. T. A. Harrison, University of Aberdeen, Scotland

Keywords: crystal structure; absolute structure; isatin derivatives; frozen chiral conformation; SHG effect; charge-transport property.

CCDC reference: 1528555

Supporting information: this article has supporting information at journals.iucr.org/e

\section{6-Chloro-1-phenylindoline-2,3-dione: absolute structure, non-linear optical and charge-transport properties}

\author{
Bing Wang, ${ }^{a}$ Qing Lu, ${ }^{a}$ Qi Fang, ${ }^{\text {a* }}$ Ting-ting Zhang ${ }^{\mathrm{b}}$ and Ying-ying Jin ${ }^{\mathrm{a}}$
}

\begin{abstract}
${ }^{a}$ State Key Laboratory of Crystal Materials, Shandong University, Jinan 250100, Shandong Province, People's Republic of China, and ${ }^{\mathbf{b}}$ School of Chemistry and Chemical Engineering, Shandong University, Jinan 250100, Shandong Province, People's Republic of China. *Correspondence e-mail: fangqi@sdu.edu.cn
\end{abstract}

In the title compound, $\mathrm{C}_{14} \mathrm{H}_{8} \mathrm{ClNO}_{2}$, the dihedral angle between the isatin moiety (r.m.s. deviation $=0.014 \AA$ ) and the phenyl ring is $51.8(1)^{\circ}$. All molecules have the same 'frozen chiral' conformation in the non-centrosymmetric $P 2_{1} 2_{1} 2_{1}$ space group. A polycrystalline sample of the title compound exhibits a considerable second-order non-linear optical effect (frequency doubling of $1064 \mathrm{~nm}$ light to output $532 \mathrm{~nm}$ light). In the crystal, molecules are linked by $\mathrm{C}-\mathrm{H} \ldots \mathrm{O}$ hydrogen bonds, generating chains along the [100] direction. Based on a DFT calculation, [100] proves to be the most favourable direction for charge transport and the title crystal could be used as a holetransport material because of its high hole mobility.

\section{Chemical context}

Derivatives of isatin, also called indoline-2,3-dione, have drawn great attention for their biological and pharmacological properties such as anticonvulsant (Prakash et al., 2010), anticancer (Abadi et al., 2006) and anti-HIV (Bal et al., 2005) activities. The isatin skeleton can be found in analytical reagents, pesticides and dye intermediates. Isatin derivatives are also versatile precursors in the synthesis of a variety of heterocyclic compounds. However, the opto-electronic properties of isatin derivatives are rarely investigated.

The crystal structures of many isatin derivatives have been reported, among the analogues of the title compound are 6-bromo-1-butylindoline-2,3-dione (Ji et al., 2009), 1-ethyl-5iodoindoline-2,3-dione (Wang et al., 2014), 6-chloroindoline2,3-dione (Golen \& Manke, 2016), 1-benzyl-5-fluoroindoline2,3-dione (Sharmila et al., 2015) and 1-phenylindoline-2,3dione (Shukla \& Rajeswaran, 2011). The synthesis of the title compound was reported in 2014 (Bergman \& Stensland, 2014). Recently, we prepared this compound by a different method, which involves the use of $\mathrm{O}_{2}$ in air as oxidant. Herein, we report the crystal structure and some opto-electronic properties of this compound.

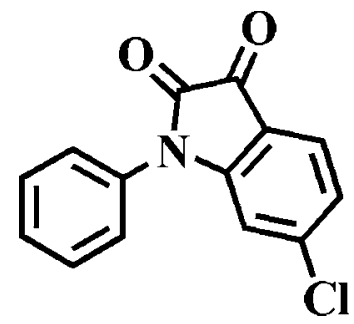




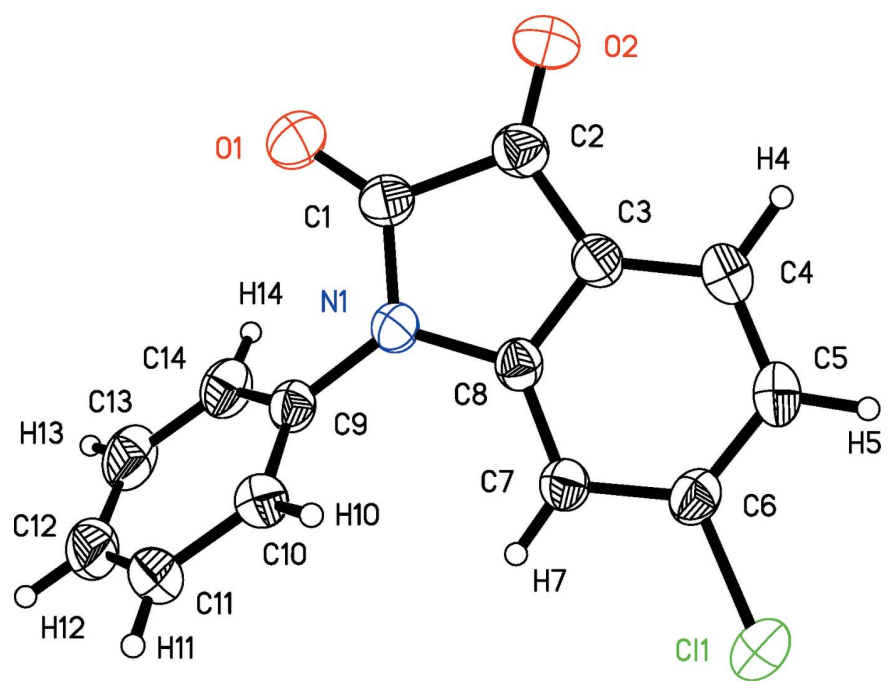

Figure 1

The molecular structure of the title compound, with displacement ellipsoids shown at the $50 \%$ probability level.

\section{Structural commentary}

As shown in Fig. 1, the isatin unit of the molecule is essentially planar, with a mean deviation of 0.009 (2) $\AA$ and a maximum deviation of 0.0870 (8) $\AA$ (for atom O1) from the mean plane of the indoline core $(\mathrm{C} 1-\mathrm{C} 8 / \mathrm{N} 1)$. As a result of the short intramolecular contacts $(\mathrm{C} 10 \cdots \mathrm{C} 7, \mathrm{C} 14 \cdots \mathrm{O} 1)$ and the $\mathrm{H} 7 \cdots \mathrm{H} 10$ steric hindrance, there is a dihedral angle of $51.8(1)^{\circ}$ between the phenyl ring and the mean plane of the indoline core. As a comparison, the dihedral angle of the DFT/ b3lyp/6-311++g $(2 \mathrm{~d}, \mathrm{p})$ optimized (see below) title molecule is $60.0^{\circ}$. The sum of the angles surrounding N1 is $359.96^{\circ}$,

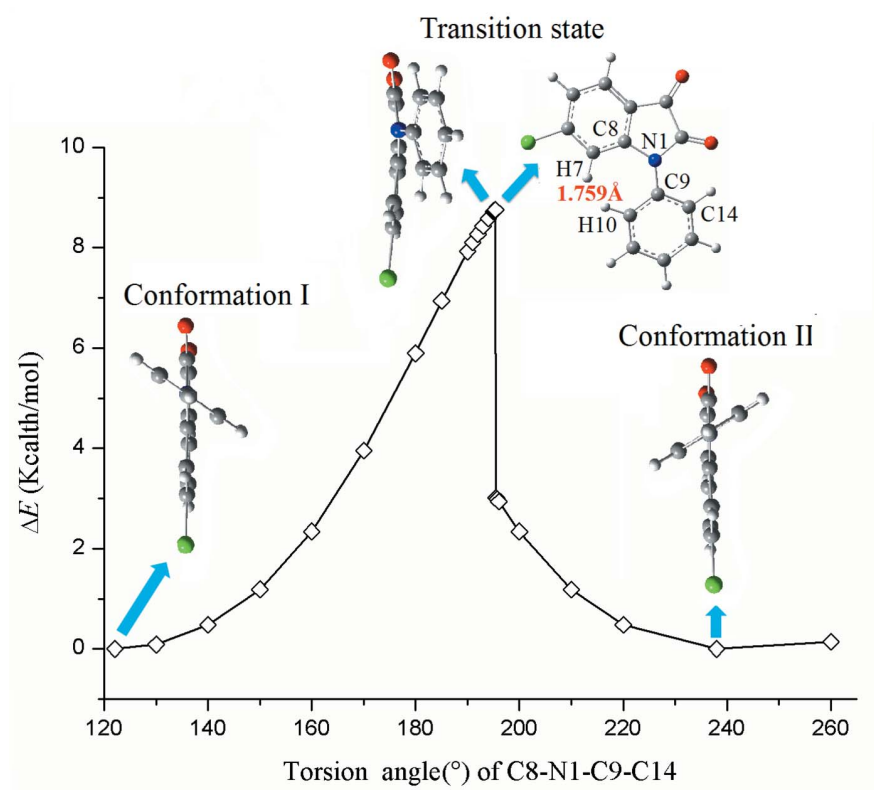

Figure 2

DFT/b3lyp/6-311++g(2 d,p) optimization of series of relaxed conformation with different $\mathrm{C} 8-\mathrm{N} 1-\mathrm{C} 9-\mathrm{C} 14$ torsion angles for the title molecule.
Table 1

Hydrogen-bond geometry $\left(\AA,^{\circ}\right)$.

\begin{tabular}{lllll}
\hline$D-\mathrm{H} \cdots A$ & $D-\mathrm{H}$ & $\mathrm{H} \cdots A$ & $D \cdots A$ & $D-\mathrm{H} \cdots A$ \\
\hline $\mathrm{C} 10-\mathrm{H} 10 \cdots \mathrm{O} 1^{\mathrm{i}}$ & $0.956(17)$ & $2.572(18)$ & $3.2063(16)$ & $124.0(13)$ \\
\hline
\end{tabular}

Symmetry code: (i) $x+1, y, z$.

suggesting that this atom is $s p^{2}$ hybridized. The $\mathrm{C} 9-\mathrm{N} 1$ bond length $[1.4279(14) \AA]$ is slightly shorter than that [1.436 (2) $\AA$ ] in the similar compound 1-phenylindoline-2,3dione (Shukla \& Rajeswaran, 2011). The C1-C2 [1.557 (2) ̊] bond length is longer than a typical $\mathrm{Csp} p^{2}-\mathrm{Csp}^{2}$ bond but it is notable that the geometry optimization gave a length of $1.568 \AA$ for this bond. The $\mathrm{C} 1-\mathrm{C} 2$ length $[1.545$ (3) $\AA]$ in 1 phenylindoline-2,3-dione is somewhat shorter (Shukla \& Rajeswaran, 2011).

As a result of the $P 2{ }_{1} 2_{1} 2_{1}$ space group of the crystal, all molecules have the same 'frozen chiral' conformation (defined as conformation I). The single conformation of these molecules in this as-tested crystal is confirmed by a Flack parameter $x=0.03$ (5) and $R_{1}$ factor of 0.0317. By comparison, an inversion operation to the present structure resulted in an incorrect structure of conformation II with $x=0.97$ (5) and $R_{1}$ $=0.0336$. 1-Phenylindoline-2,3-dione also crystallized in $P 2{ }_{1} 2_{1} 2_{1}$ (Shukla \& Rajeswaran, 2011) and this space group may be well suited to accommodate this class of molecules.

As shown in Figs. 1 and 2, the isoenergic conformations I and II are mirror images and non-superposable one another. The calculated rotation barrier (rotating around the $\mathrm{N} 1-\mathrm{C} 9$ bond to transform from I to II) is $8.74 \mathrm{kcal} \mathrm{mol}^{-1}$, which is much higher than the thermal energy $k_{\mathrm{B}} T=0.596 \mathrm{kcal} \mathrm{mol}^{-1}$ at $300 \mathrm{~K}$. The main hindrance from free rotation may be the H7 $\cdots$ H10 steric repulsion with a calculated distance of $1.759 \AA$ at the transition state (see Fig. 2).

\section{Supramolecular features}

As shown in Fig. 3, the intermolecular interactions in the $a$ axis direction are characterized by a $\mathrm{C} 10-\mathrm{H} 10 \cdots \mathrm{O} 1$ hydrogen bond (Table 1) and an $\mathrm{O} 1 \cdots \operatorname{H11}(x-1, y, z)$ [2.63 (2) §]] short contact between two side-by-side molecules. The strength of the hydrogen bond can be scaled by the electronic transfer integral $(t)$ between two molecules and it was calculated by equation (3). The $t$ value between the above two adjacent molecules is maximal $\left(t_{1}=0.196 \mathrm{eV}\right)$, indicating that a kind of side-by-side one-dimensional chain has formed along the $a$-axis direction. We believe that this $a$-directional chain plays an important role in guiding the crystal growth, for the long axis of the bar-shaped crystal was indexed to be in the [100] direction.

By the $2{ }_{1}[010]$ screw operation, molecules are packed into columns along the $b$-axis direction involving $\mathrm{C} 2 \cdots \mathrm{C} 12(2-x$, $\left.\frac{1}{2}+y, \frac{3}{2}-z\right)[3.280(2) \AA]$ and $\mathrm{H} 10 \cdots \mathrm{C} 14\left(2-x, \frac{1}{2}+y, \frac{3}{2}-z\right)$ [2.50 (3) $\AA$ ] short intermolecular contacts between two neighboring molecules (see Fig. 4). The transfer integral 


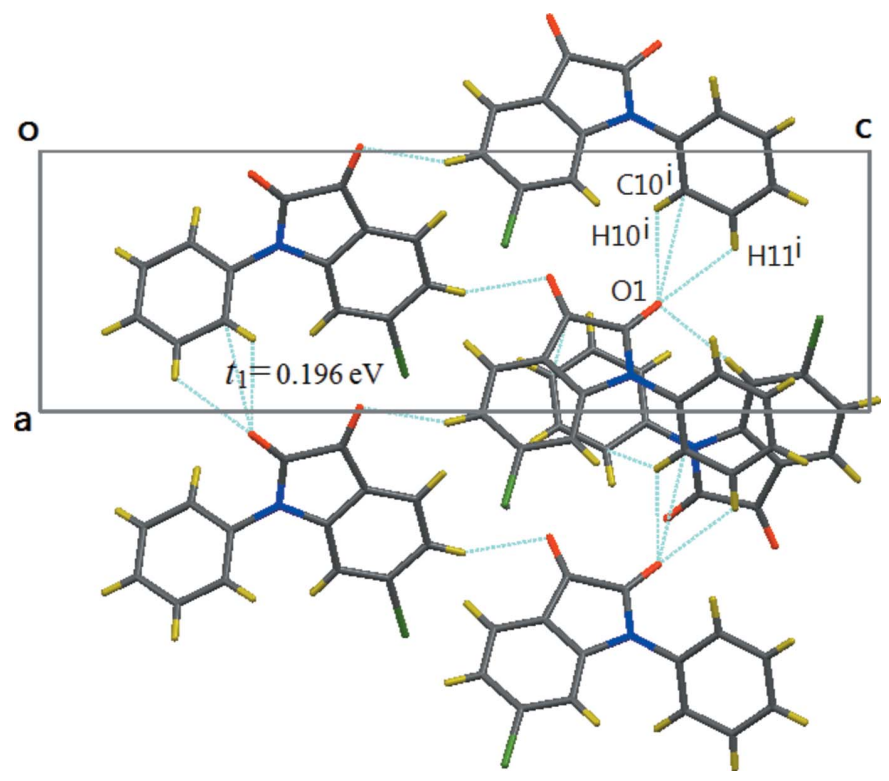

Figure 3

The view along the $b$ axis, showing the chain linkage by the $\mathrm{C} 10^{\mathrm{i}}-$ $\mathrm{H} 10^{\mathrm{i}} \cdots \mathrm{O} 1$ hydrogen bond and the $\mathrm{O} 1 \cdots \mathrm{H} 11^{\mathrm{i}}$ short intermolecular contacts along the $a$-axis direction. [Symmetry code: (i) $-1+x, y, z$.]

between such two face-to-face molecules is somewhat smaller $\left(t_{2}=0.116 \mathrm{eV}\right)$ in this direction.

Along the $c$-axis direction, there is a $\mathrm{H} 5 \cdots \mathrm{O} 2\left(\frac{1}{2}+x, \frac{3}{2}-y\right.$, $1-z)[2.69$ (2) A] short intermolecular contact and the $t$ value between the two molecules is a minimum $\left(t_{3}=0.0794 \mathrm{eV}\right.$, see Fig. 4): thus the intermolecular interactions in this direction are relatively weak.

\section{Calculation and opto-electronic properties}

It is well known that the necessary structural condition for second-order non-linear optical response is non-centrosymmetry, both for molecules and crystals. The $P 2_{1} 2_{1} 2_{1}$ space group of the crystal prompted us to make a SHG (second harmonic generation) test. When the sample of crystalline

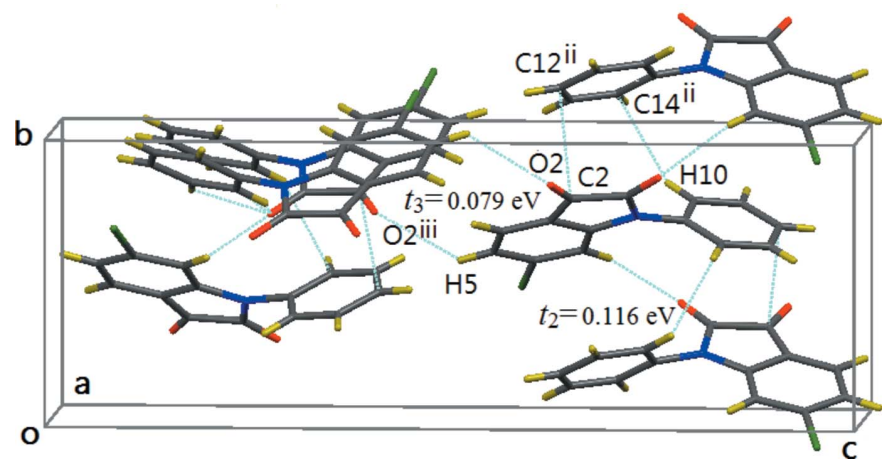

Figure 4

The view along the $a$ axis, showing the columnar structure and short contacts of $\mathrm{C} 2 \cdots \mathrm{C} 12^{\mathrm{ii}}$ and $\mathrm{H} 10 \cdots \mathrm{C} 14^{\mathrm{ii}}$ along the $b$-axis direction, also showing the short contact of $\mathrm{H} 5 \cdots \mathrm{O} 22^{\mathrm{iii}}$ along the $c$ direction. [Symmetry codes: (ii) $2-x, \frac{1}{2}+y, \frac{3}{2}-z$; (iii) $\frac{1}{2}+x, \frac{3}{2}-y, 1-z$.]

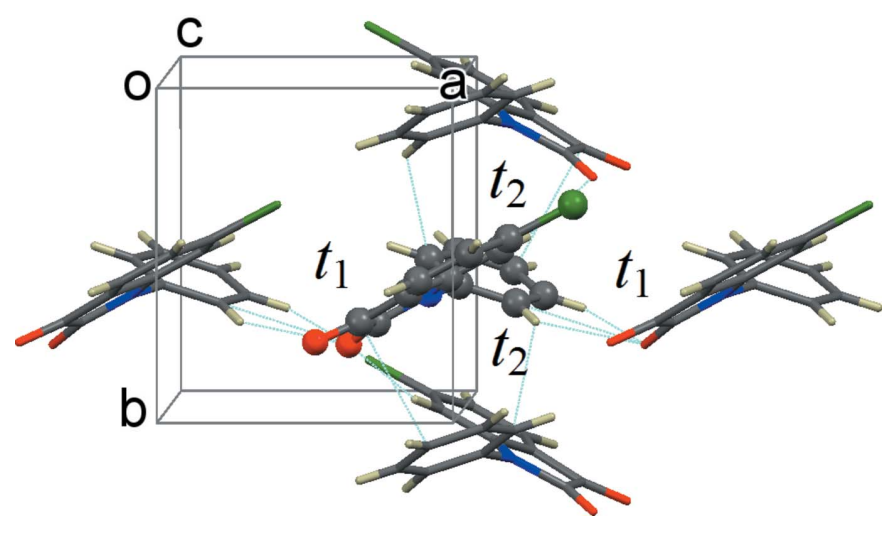

Figure 5

The view along the $c$ axis, showing the cage-model for the DFT geometry optimization with one host molecule being surrounded by four guest molecules.

powder was irradiated with infrared laser pulses $(1064 \mathrm{~nm})$, green light pulses $(532 \mathrm{~nm})$ could be observed.

Density functional theory (DFT) calculations for the electronic transfer integral $t$ and the reorganization energy $\lambda$, were carried out using the GAUSSIAN03 program (Frisch et al., 2003) within the framework of b3lyp/6-311g(d).

The charge transport in organic semiconductors can be described by the hopping of an electron between a molecule and a neighbouring cation (hole) or anion shown below

$$
\begin{aligned}
& M \cdots M^{+} \rightarrow M^{+} \cdots M \\
& M \cdots M^{-} \rightarrow M^{-} \cdots M
\end{aligned}
$$

Based on the Marcus electron-transfer theory (Marcus, 1993), the mobility $(\mu)$ in a one-dimensional uniform structure, can be expressed as (Sakanoue et al., 1999; Fang et al., 2015)

$$
\mu=\frac{e}{2 k_{\mathrm{B}} T \hbar}\left(\frac{\pi}{\lambda k_{\mathrm{B}} T}\right)^{1 / 2} d^{2} t^{2} \exp \left(-\frac{\lambda}{4 k_{\mathrm{B}} T}\right)
$$

where $d$ is the distance between two neighbouring molecules and $\lambda$ is reorganization energy. For the hole transport, $\lambda$ can be expressed by (Berlin et al., 2003)

$$
\lambda=\lambda_{1}+\lambda_{2}=\left(E_{+}^{0}-E_{0}^{0}\right)+\left(E_{0}^{+}-E_{+}^{+}\right) .
$$

Thus, $\lambda_{1}$ measures the energy difference between the stable molecule and the molecule with the cation geometry and $\lambda_{2}$ measures the energy difference between the stable cation and the cation with the molecule geometry.

The $t$ in equation (1) is the electronic transfer integral, which measures the intermolecular interactions between two neighbouring molecules and can be calculated by (Deng \& Goddard, 2004)

$$
t=\left(E_{\mathrm{HOMO}}-E_{\mathrm{HOMO}-1}\right) / 2
$$

where $E_{\mathrm{HOMO}}$ and $E_{\mathrm{HOMO}-1}$ are the energy levels of the HOMO (highest occupied molecular orbital) and the HOMO1 orbital of a two-molecule pair, respectively.

The molecular geometry for the $t$ calculation is based on this $\mathrm{X}$-ray structure without optimization, while the geometries of 
Table 2

Charge-transport properties $\left(\mathrm{eV}, \mathrm{cm}^{2} \mathrm{~V}^{-1} \mathrm{~s}^{-1}\right)$ of the title crystal.

\begin{tabular}{llll}
\hline & $t$ & $\lambda_{\mathrm{h}}\left(\lambda_{\mathrm{e}}\right)$ & $\mu_{\mathrm{h}}\left(\mu_{\mathrm{e}}\right)$ \\
\hline side-by-side [100] & 0.196 & $0.319(0.520)$ & $4.67(0.524)$ \\
face-to-face [010] & 0.116 & $0.319(0.520)$ & $0.518(0.058)$ \\
\hline
\end{tabular}

the molecule and the cation/anion have been optimized for the $\lambda$ calculation. Since the molecule in the crystal is different from the free molecule, we adopted the cage model (Fang et $a l ., 2015)$ in the course of geometry optimization, in which the host (molecule or cation or anion) being optimized is constrained by four guest molecules with fixed X-ray structures (see Fig. 5).

As shown in Table 2, (i) the hole mobility $\left(\mu_{\mathrm{h}}\right)$ is one order of magnitude larger than the electron mobility $\left(\mu_{\mathrm{e}}\right)$, indicating that the title crystal could be used as a hole-transport material rather than an electron-transport material and (ii) both the hole mobility $\left(\mu_{\mathrm{h}}\right)$ and the electron mobility $\left(\mu_{\mathrm{e}}\right)$ in the [100] direction (the side-by-side chain direction) are an order of magnitude larger than those in the [010] direction (the face-toface column direction).

In summary, the side-by-side hydrogen bonding in the onedimensional chain in the [100] direction is stronger than the face-to-face $\pi-\pi$ interactions in the [010] direction for this crystal, which relates to the non-linear optical and electronic transport properties of the crystal.

\section{Database survey}

A search in the Cambridge Structural Database (WebCSD, Version 1.1.2; last update November 2016), for indoline-2,3dione derivatives gave 137 hits. Among them, there are nine hits for halogen 6-substituted indoline-2,3-dione derivatives and two hits which contain the substructure of the 1-phenylindoline-2,3-dione skeleton. There are four non-centrosymmetric structures and seven centrosymmetric structures among these eleven crystal structures.

\section{Synthesis and crystallization}

We synthesized the title compound by the reaction of 6-chloroindoline-2-one and phenylboronic acid (see Fig. 6). 6-Chloroindoline-2-one $(0.168 \mathrm{~g}, 1.00 \mathrm{mmol})$ was dissolved in DMF $(18 \mathrm{ml})$. Then pyridine $(0.05 \mathrm{~mL})$, phenylboronic acid $(0.244 \mathrm{~g}, 2.00 \mathrm{mmol})$ and $\mathrm{Cu}(\mathrm{OAc})_{2} \cdot \mathrm{H}_{2} \mathrm{O}(0.197 \mathrm{~g}, 0.99 \mathrm{mmol})$ were sequentially added into the flask. The mixture was stirred

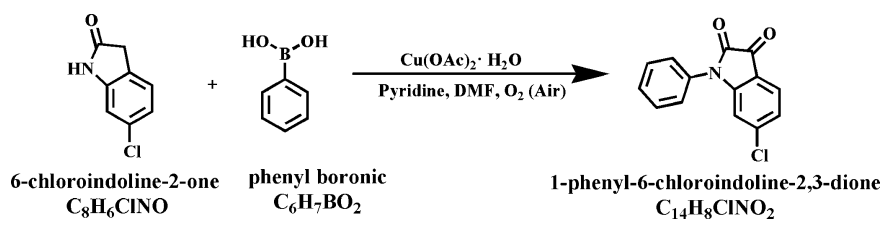

Figure 6

Reaction scheme.
Table 3

Experimental details.

\begin{tabular}{ll}
\hline Crystal data & \\
Chemical formula & $\mathrm{C}_{14} \mathrm{H}_{8} \mathrm{ClNO}_{2}$ \\
$M_{\mathrm{r}}$ & 257.66 \\
Crystal system, space group & Orthorhombic, $P 2{ }_{1} 2_{1} 2_{1}$ \\
Temperature $(\mathrm{K})$ & 294 \\
$a, b, c(\AA)$ & $6.8190(3), 7.7062(3), 21.7492(9)$ \\
$V\left(\AA^{3}\right)$ & $1142.89(8)$ \\
$Z$ & 4 \\
Radiation type & Mo $K \alpha$ \\
$\mu\left(\mathrm{mm}^{-1}\right)$ & 0.33 \\
Crystal size $(\mathrm{mm})$ & $0.58 \times 0.24 \times 0.18$ \\
& \\
Data collection & Bruker APEXII CCD \\
Diffractometer & Multi-scan $(S A D A B S ;$ Bruker, \\
Absorption correction & $2005)$ \\
& $0.834,0.943$ \\
$T_{\text {min }}, T_{\text {max }}$ & $21380,3784,3513$ \\
No. of measured, independent and & \\
$\quad$ observed $[I>2 \sigma(I)]$ reflections & 0.021 \\
$R_{\text {int }}$ & 0.741 \\
(sin $\theta / \lambda)_{\text {max }}\left(\AA^{-1}\right)$ & \\
& \\
Refinement & \\
$R\left[F^{2}>2 \sigma\left(F^{2}\right)\right], w R\left(F^{2}\right), S$ & $0.032,0.090,1.04$ \\
No. of reflections & 3784 \\
No. of parameters & 191 \\
H-atom treatment & H atoms treated by a mixture of \\
& independent and constrained \\
$\Delta \rho_{\text {max }}, \Delta \rho_{\text {min }}\left(\mathrm{e} \AA^{-3}\right)$ & refinement \\
Absolute structure & $0.21,-0.23$ \\
Absolute structure parameter & Flack $(1983), 1583$ Friedel pairs \\
\hline & $0.03(5)$ \\
\hline &
\end{tabular}

Computer programs: APEX2 and SAINT (Bruker, 2005), SHELXS97, SHELXL97 and SHELXTL (Sheldrick, 2008).

for two $h$ at room temperature in the presence of air. After filtration, the filtrate was poured into $100 \mathrm{ml}$ water and

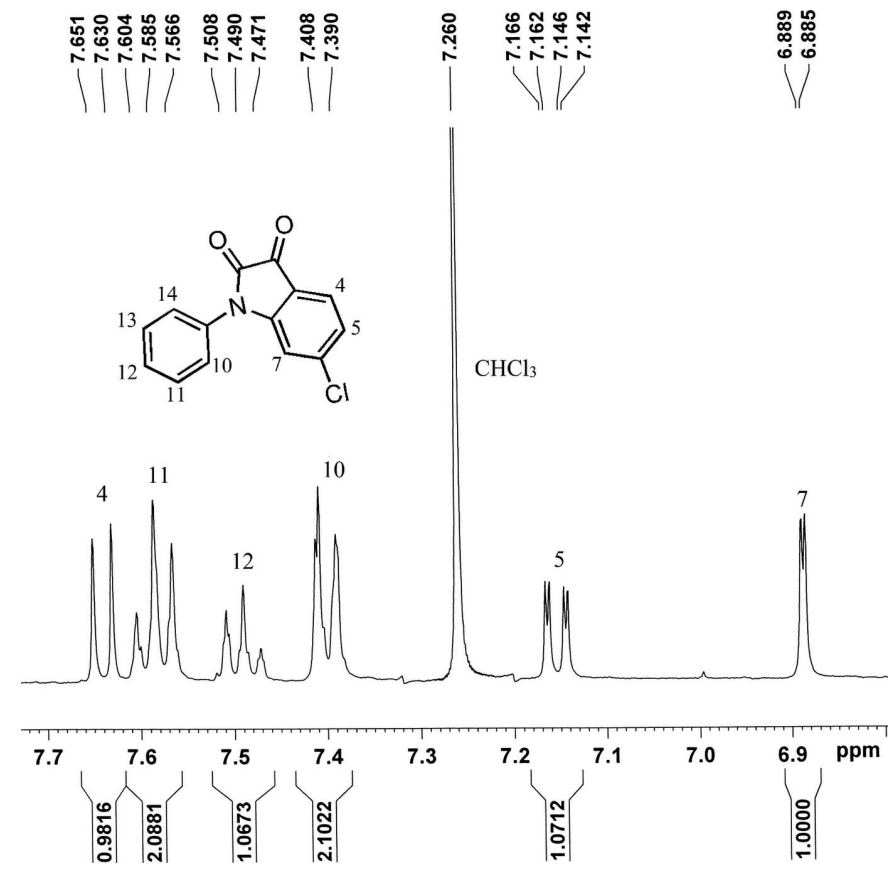

Figure 7

The ${ }^{1} \mathrm{H}$ NMR spectra of the title compound. 
extracted with dichloromethane. The organic phase was washed by water and dried by anhydrous $\mathrm{Na}_{2} \mathrm{SO}_{4}$. The crude product was purified by silica gel chromatography, eluting with a mixture of petroleum ether:ethyl acetate (30:1) to obtain an orange solid (0.096 g, yield 37\%). ${ }^{1} \mathrm{H}$ NMR (400 $\mathrm{MHz}, \mathrm{CDCl}_{3}$ ) $\delta 7.64(d, J=8.4 \mathrm{~Hz}, 1 \mathrm{H}), 7.59(t, J=7.6 \mathrm{~Hz}, 2 \mathrm{H}), 7.49(t, J=$ $7.4 \mathrm{~Hz}, 1 \mathrm{H}), 7.40(d, J=7.2 \mathrm{~Hz}, 2 \mathrm{H}), 7.15(d d, J=8.0,1.6 \mathrm{~Hz}$, $1 \mathrm{H}), 6.89(d, J=1.6 \mathrm{~Hz}, 1 \mathrm{H})$. As shown in Fig. 7, the ${ }^{1} \mathrm{H}$ NMR signals of all protons of the compound are well separated and well characterized. Orange bar-shaped crystals were obtained by slow evaporation of a solution of the title compound in mixed solvents of dichloromethane and $n$-hexane.

\section{Refinement}

Crystal data, diffraction data and structure refinement details are summarized in Table 3. All hydrogen atoms were located from the difference-electron-density maps and refined freely, resulting in $\mathrm{C}-\mathrm{H}$ lengths ranging from 0.92 (2) to 1.00 (2) A.

\section{Funding information}

Funding for this research was provided by: National Natural Science Foundation of China (award Nos. 21472116, 20972089); Key Laboratory of Crystal Materials.

\section{References}

Abadi, A. H., Abou-Seri, S. M., Abdel-Rahman, D. E., Klein, C., Lozach, O. \& Meijer, L. (2006). Eur. J. Med. Chem. 41, 296-305.

Bal, T. R., Anand, B., Yogeeswari, P. \& Sriram, D. (2005). Bioorg. Med. Chem. Lett. 15, 4451-4455.

Bergman, J. \& Stensland, B. (2014). J. Heterocycl. Chem. 51, 1-10.

Berlin, Y. A., Hutchison, G. R., Rempala, P., Ratner, M. A. \& Michl, J. (2003). J. Phys. Chem. A, 107, 3970-3980.

Bruker (2005). APEX2, SAINT and SADABS. Bruker AXS Inc., Madison, Wisconsin, USA.

Deng, W.-Q. \& Goddard, W. A. III (2004). J. Phys. Chem. B, 108, 8614-8621.

Fang, Q., Chen, H., Lei, H., Xue, G. \& Chen, X. (2015). CrystEngComm, 17, 787-796.

Flack, H. D. (1983). Acta Cryst. A39, 876-881.

Frisch, M. J., et al. (2003). GAUSSIAN03. Gaussian Inc., Pittsburgh, PA, USA.

Golen, J. A. \& Manke, D. R. (2016). IUCrData, 1, x160690.

Ji, L., Fang, Q. \& Fan, J. (2009). Acta Cryst. E65, o136.

Marcus, R. A. (1993). Rev. Mod. Phys. 65, 599-610.

Prakash, C. R., Raja, S. \& Saravanan, G. (2010). Int. J. Pharm. Pharm. Sci. 2, 177-181.

Sakanoue, K., Motoda, M., Sugimoto, M. \& Sakaki, S. (1999). J. Phys. Chem. A, 103, 5551-5556.

Sharmila, N., Sundar, T. V., Satish, G., Ilangovan, A. \& Venkatesan, P. (2015). Acta Cryst. C71, 975-978.

Sheldrick, G. M. (2008). Acta Cryst. A64, 112-122.

Shukla, D. \& Rajeswaran, M. (2011). Acta Cryst. E67, o2034.

Wang, L., Shen, Y.-X., Dong, J.-T., Zhang, M. \& Fang, Q. (2014). Acta Cryst. E70, o67. 


\section{supporting information}

Acta Cryst. (2017). E73, 908-912 [https://doi.org/10.1107/S2056989017007630]

\section{6-Chloro-1-phenylindoline-2,3-dione: absolute structure, non-linear optical and charge-transport properties}

Bing Wang, Qing Lu, Qi Fang, Ting-ting Zhang and Ying-ying Jin

Computing details

Data collection: APEX2 (Bruker, 2005); cell refinement: SAINT (Bruker, 2005); data reduction: SAINT (Bruker, 2005); program(s) used to solve structure: SHELXS97 (Sheldrick, 2008); program(s) used to refine structure: SHELXL97

(Sheldrick, 2008); molecular graphics: SHELXTL (Sheldrick, 2008); software used to prepare material for publication:

SHELXTL (Sheldrick, 2008).

6-Chloro-1-phenylindoline-2,3-dione

Crystal data

$\mathrm{C}_{14} \mathrm{H}_{8} \mathrm{ClNO}_{2}$

$M_{r}=257.66$

Orthorhombic, $P 22_{1} 2_{1} 2_{1}$

$a=6.8190(3) \AA$

$b=7.7062(3) \AA$

$c=21.7492(9) \AA$

$V=1142.89(8) \AA^{3}$

$Z=4$

$D_{\mathrm{x}}=1.497 \mathrm{Mg} \mathrm{m}^{-3}$

Mo $K \alpha$ radiation, $\lambda=0.71073 \AA$

Cell parameters from 9992 reflections

$\theta=2.8-31.0^{\circ}$

$\mu=0.33 \mathrm{~mm}^{-1}$

$T=294 \mathrm{~K}$

Bar, orange

$F(000)=528$

$0.58 \times 0.24 \times 0.18 \mathrm{~mm}$

Data collection

Bruker APEXII CCD

diffractometer

Radiation source: fine-focus sealed tube

Graphite monochromator

Detector resolution: 8.3 pixels $\mathrm{mm}^{-1}$

$\omega$ scans

Absorption correction: multi-scan

(SADABS; Bruker, 2005)

$T_{\min }=0.834, T_{\max }=0.943$

21380 measured reflections

3784 independent reflections

3513 reflections with $I>2 \sigma(I)$

$R_{\text {int }}=0.021$

$\theta_{\text {max }}=31.8^{\circ}, \theta_{\min }=1.9^{\circ}$

$h=-9 \rightarrow 9$

$k=-10 \rightarrow 11$

$l=-32 \rightarrow 28$

Refinement

Refinement on $F^{2}$

Least-squares matrix: full

$R\left[F^{2}>2 \sigma\left(F^{2}\right)\right]=0.032$

$w R\left(F^{2}\right)=0.090$

$S=1.04$

3784 reflections

191 parameters

0 restraints

Primary atom site location: structure-invariant

direct methods

Secondary atom site location: difference Fourier map

Hydrogen site location: mixed

$\mathrm{H}$ atoms treated by a mixture of independent and constrained refinement

$w=1 /\left[\sigma^{2}\left(F_{\mathrm{o}}^{2}\right)+(0.0575 P)^{2}+0.0865 P\right]$

where $P=\left(F_{\mathrm{o}}{ }^{2}+2 F_{\mathrm{c}}{ }^{2}\right) / 3$

$(\Delta / \sigma)_{\max }=0.001$

$\Delta \rho_{\max }=0.21 \mathrm{e}^{-3}$

$\Delta \rho_{\min }=-0.23 \mathrm{e} \AA^{-3}$ 
Absolute structure: Flack (1983), 1583 Friedel pairs

\section{Special details}

Experimental. Scan width $0.5^{\circ} \omega$, Crystal to detector distance $5.96 \mathrm{~cm}$, exposure time $15 \mathrm{~s}, 10$ hours and 36 minutes for data collection, with scale. 6-run at 2 theta equal $-28,-28,-35,-36,-36,-38$, respectively.

Geometry. All esds (except the esd in the dihedral angle between two 1.s. planes) are estimated using the full covariance matrix. The cell esds are taken into account individually in the estimation of esds in distances, angles and torsion angles; correlations between esds in cell parameters are only used when they are defined by crystal symmetry. An approximate (isotropic) treatment of cell esds is used for estimating esds involving l.s. planes.

Refinement. Refinement of $\mathrm{F}^{2}$ against ALL reflections. The weighted R-factor $\mathrm{wR}$ and goodness of fit $\mathrm{S}$ are based on $\mathrm{F}^{2}$, conventional R-factors $R$ are based on $F$, with $F$ set to zero for negative $F^{2}$. The threshold expression of $F^{2}>2$ sigma $\left(F^{2}\right)$ is used only for calculating R-factors ( $\mathrm{gt}$ ) etc. and is not relevant to the choice of reflections for refinement. R-factors based on $\mathrm{F}^{2}$ are statistically about twice as large as those based on F, and R- factors based on ALL data will be even larger.

Fractional atomic coordinates and isotropic or equivalent isotropic displacement parameters $\left(\AA^{2}\right)$

\begin{tabular}{lllll}
\hline & $x$ & $y$ & $z$ & $U_{\text {iso }} / U_{\text {eq }}$ \\
\hline C11 & $1.36000(5)$ & $0.40110(5)$ & $0.561115(17)$ & $0.05229(11)$ \\
C7 & $1.10733(16)$ & $0.54301(15)$ & $0.64149(5)$ & $0.0323(2)$ \\
O2 & $0.48463(15)$ & $0.81725(15)$ & $0.61436(5)$ & $0.0514(3)$ \\
O1 & $0.58784(14)$ & $0.83661(15)$ & $0.74488(5)$ & $0.0466(2)$ \\
C5 & $1.0114(2)$ & $0.5438(2)$ & $0.53283(6)$ & $0.0423(3)$ \\
C6 & $1.14176(18)$ & $0.50392(15)$ & $0.57981(5)$ & $0.0355(2)$ \\
C8 & $0.93314(16)$ & $0.62745(14)$ & $0.65401(5)$ & $0.0298(2)$ \\
N1 & $0.86151(14)$ & $0.68187(13)$ & $0.71209(4)$ & $0.03287(18)$ \\
C9 & $0.95746(17)$ & $0.65986(15)$ & $0.76993(5)$ & $0.0309(2)$ \\
C14 & $0.8529(2)$ & $0.58710(17)$ & $0.81830(6)$ & $0.0400(3)$ \\
C13 & $0.9437(3)$ & $0.5724(2)$ & $0.87499(6)$ & $0.0502(3)$ \\
H13 & 0.8757 & 0.5247 & 0.9080 & $0.060^{*}$ \\
C12 & $1.1351(3)$ & $0.6281(2)$ & $0.88297(6)$ & $0.0539(4)$ \\
C3 & $0.79945(17)$ & $0.66972(16)$ & $0.60753(5)$ & $0.0339(2)$ \\
C4 & $0.8377(2)$ & $0.62747(18)$ & $0.54664(6)$ & $0.0417(3)$ \\
C2 & $0.63341(17)$ & $0.75880(16)$ & $0.63578(6)$ & $0.0366(2)$ \\
C1 & $0.68398(16)$ & $0.76703(16)$ & $0.70553(6)$ & $0.0348(2)$ \\
C11 & $1.2390(2)$ & $0.6983(2)$ & $0.83442(6)$ & $0.0456(3)$ \\
C10 & $1.15006(18)$ & $0.71514(15)$ & $0.77716(5)$ & $0.0350(2)$ \\
H5 & $1.042(3)$ & $0.510(2)$ & $0.4916(9)$ & $0.056(5)^{*}$ \\
H4 & $0.739(3)$ & $0.659(2)$ & $0.5147(9)$ & $0.050(5)^{*}$ \\
H10 & $1.219(3)$ & $0.768(2)$ & $0.7437(8)$ & $0.041(4)^{*}$ \\
H11 & $1.369(3)$ & $0.735(2)$ & $0.8379(9)$ & $0.054(5)^{*}$ \\
H12 & $1.195(4)$ & $0.618(3)$ & $0.9210(11)$ & $0.081(7)^{*}$ \\
H14 & $0.724(3)$ & $0.548(3)$ & $0.8112(9)$ & $0.056(5)^{*}$ \\
H7 & $1.195(3)$ & $0.509(2)$ & $0.6711(8)$ & $0.038(4)^{*}$ \\
& & & & \\
\end{tabular}

Atomic displacement parameters $\left(\AA^{2}\right)$

\begin{tabular}{lllllll}
\hline & $U^{11}$ & $U^{22}$ & $U^{33}$ & $U^{12}$ & $U^{13}$ & $U^{23}$ \\
\hline C11 & $0.04536(17)$ & $0.0669(2)$ & $0.04463(17)$ & $0.01248(15)$ & $0.01136(13)$ & $-0.00487(15)$
\end{tabular}




$\begin{array}{lllllll}\text { C7 } & 0.0316(5) & 0.0373(5) & 0.0281(4) & 0.0001(4) & 0.0017(4) & 0.0021(4) \\ \text { O2 } & 0.0373(4) & 0.0633(6) & 0.0536(6) & 0.0104(4) & -0.0091(4) & -0.0017(5) \\ \text { O1 } & 0.0361(4) & 0.0589(6) & 0.0448(5) & 0.0057(4) & 0.0071(4) & -0.0055(4) \\ \text { C5 } & 0.0491(7) & 0.0514(7) & 0.0263(5) & 0.0011(5) & 0.0025(4) & -0.0016(5) \\ \text { C6 } & 0.0352(5) & 0.0391(5) & 0.0324(5) & 0.0011(4) & 0.0071(4) & -0.0003(4) \\ \text { C8 } & 0.0299(4) & 0.0330(5) & 0.0265(4) & -0.0031(4) & 0.0022(3) & 0.0008(4) \\ \text { N1 } & 0.0281(4) & 0.0435(5) & 0.0270(4) & 0.0015(4) & 0.0026(3) & -0.0012(3) \\ \text { C9 } & 0.0354(5) & 0.0315(5) & 0.0260(4) & 0.0013(4) & 0.0026(4) & -0.0002(4) \\ \text { C14 } & 0.0468(7) & 0.0381(5) & 0.0353(5) & -0.0017(5) & 0.0102(5) & 0.0016(4) \\ \text { C13 } & 0.0712(9) & 0.0490(7) & 0.0305(6) & 0.0122(7) & 0.0121(6) & 0.0080(5) \\ \text { C12 } & 0.0714(9) & 0.0600(8) & 0.0303(5) & 0.0256(8) & -0.0083(6) & -0.0015(5) \\ \text { C3 } & 0.0328(5) & 0.0384(5) & 0.0305(5) & -0.0006(4) & -0.0017(4) & 0.0013(4) \\ \text { C4 } & 0.0463(6) & 0.0490(6) & 0.0299(5) & 0.0021(5) & -0.0053(5) & 0.0005(5) \\ \text { C2 } & 0.0313(5) & 0.0400(5) & 0.0385(5) & -0.0019(4) & -0.0019(4) & 0.0001(4) \\ \text { C1 } & 0.0280(5) & 0.0393(5) & 0.0372(5) & -0.0014(4) & 0.0017(4) & -0.0001(4) \\ \text { C11 } & 0.0453(7) & 0.0527(7) & 0.0388(6) & 0.0106(6) & -0.0109(5) & -0.0067(6) \\ \text { C10 } & 0.0343(5) & 0.0381(5) & 0.0327(5) & 0.0017(4) & -0.0004(4) & -0.0005(4)\end{array}$

Geometric parameters (A, $\stackrel{\circ}{)}$

\begin{tabular}{llll}
\hline $\mathrm{C} 11-\mathrm{C} 6$ & $1.7343(12)$ & $\mathrm{C} 9-\mathrm{C} 10$ & $1.3896(16)$ \\
$\mathrm{C} 7-\mathrm{C} 8$ & $1.3815(16)$ & $\mathrm{C} 14-\mathrm{C} 13$ & $1.384(2)$ \\
$\mathrm{C} 7-\mathrm{C} 6$ & $1.3948(15)$ & $\mathrm{C} 14-\mathrm{H} 14$ & $0.94(2)$ \\
$\mathrm{C} 7-\mathrm{H} 7$ & $0.916(17)$ & $\mathrm{C} 13-\mathrm{C} 12$ & $1.385(3)$ \\
$\mathrm{O} 2-\mathrm{C} 2$ & $1.2039(16)$ & $\mathrm{C} 13-\mathrm{H} 13$ & 0.9300 \\
$\mathrm{O} 1-\mathrm{C} 1$ & $1.2040(15)$ & $\mathrm{C} 12-\mathrm{C} 11$ & $1.382(2)$ \\
$\mathrm{C} 5-\mathrm{C} 4$ & $1.3816(19)$ & $\mathrm{C} 12-\mathrm{H} 12$ & $0.93(2)$ \\
$\mathrm{C} 5-\mathrm{C} 6$ & $1.3889(18)$ & $\mathrm{C} 3-\mathrm{C} 4$ & $1.3884(17)$ \\
$\mathrm{C} 5-\mathrm{H} 5$ & $0.96(2)$ & $\mathrm{C} 3-\mathrm{C} 2$ & $1.4597(17)$ \\
$\mathrm{C} 8-\mathrm{C} 3$ & $1.3996(15)$ & $\mathrm{C} 4-\mathrm{H} 4$ & $1.00(2)$ \\
$\mathrm{C} 8-\mathrm{N} 1$ & $1.4179(13)$ & $\mathrm{C} 2-\mathrm{C} 1$ & $1.5570(17)$ \\
$\mathrm{N} 1-\mathrm{C} 1$ & $1.3844(14)$ & $\mathrm{C} 11-\mathrm{C} 10$ & $0.93(2)$ \\
$\mathrm{N} 1-\mathrm{C} 9$ & $1.4279(14)$ & $\mathrm{C} 11-\mathrm{H} 11$ & $0.956(17)$ \\
$\mathrm{C} 9-\mathrm{C} 14$ & $1.3892(16)$ & $\mathrm{C} 10-\mathrm{H} 10$ & 119.7 \\
& & & $120.60(13)$ \\
$\mathrm{C} 8-\mathrm{C} 7-\mathrm{C} 6$ & $115.85(11)$ & $\mathrm{C} 12-\mathrm{C} 13-\mathrm{H} 13$ & $119.1(16)$ \\
$\mathrm{C} 8-\mathrm{C} 7-\mathrm{H} 7$ & $123.8(11)$ & $\mathrm{C} 11-\mathrm{C} 12-\mathrm{C} 13$ & $120.3(16)$ \\
$\mathrm{C} 6-\mathrm{C} 7-\mathrm{H} 7$ & $120.3(11)$ & $\mathrm{C} 11-\mathrm{C} 12-\mathrm{H} 12$ & $120.79(11)$ \\
$\mathrm{C} 4-\mathrm{C} 5-\mathrm{C} 6$ & $119.46(11)$ & $\mathrm{C} 13-\mathrm{C} 12-\mathrm{H} 12$ & $131.11(11)$ \\
$\mathrm{C} 4-\mathrm{C} 5-\mathrm{H} 5$ & $121.2(12)$ & $\mathrm{C} 4-\mathrm{C} 3-\mathrm{C} 8$ & $108.10(10)$ \\
$\mathrm{C} 6-\mathrm{C} 5-\mathrm{H} 5$ & $119.3(12)$ & $\mathrm{C} 4-\mathrm{C} 3-\mathrm{C} 2$ & $118.56(11)$ \\
$\mathrm{C} 5-\mathrm{C} 6-\mathrm{C} 7$ & $123.52(11)$ & $\mathrm{C} 8-\mathrm{C} 3-\mathrm{C} 2$ & $122.6(11)$ \\
$\mathrm{C} 5-\mathrm{C} 6-\mathrm{C} 11$ & $118.54(9)$ & $\mathrm{C} 5-\mathrm{C} 4-\mathrm{C} 3$ & $118.8(11)$ \\
$\mathrm{C} 7-\mathrm{C} 6-\mathrm{C} 11$ & $117.94(10)$ & $\mathrm{C} 5-\mathrm{C} 4-\mathrm{H} 4$ & $131.81(12)$ \\
$\mathrm{C} 7-\mathrm{C} 8-\mathrm{C} 3$ & $121.83(10)$ & $\mathrm{C} 3-\mathrm{C} 4-\mathrm{H} 4$ & $104.92(10)$ \\
$\mathrm{C} 7-\mathrm{C} 8-\mathrm{N} 1$ & $127.67(10)$ & $\mathrm{O} 2-\mathrm{C} 2-\mathrm{C} 3$ & \\
$\mathrm{C} 3-\mathrm{C} 8-\mathrm{N} 1$ & $110.50(10)$ & $\mathrm{O} 2-\mathrm{C} 2-\mathrm{C} 1$ & $\mathrm{C} 3-\mathrm{C} 2-\mathrm{C} 1$ \\
$\mathrm{C} 1-\mathrm{N} 1-\mathrm{C} 8$ & $110.46(9)$ & &
\end{tabular}




\begin{tabular}{|c|c|c|c|}
\hline $\mathrm{C} 1-\mathrm{N} 1-\mathrm{C} 9$ & $123.21(9)$ & $\mathrm{O} 1-\mathrm{C} 1-\mathrm{N} 1$ & $127.88(12)$ \\
\hline $\mathrm{C} 8-\mathrm{N} 1-\mathrm{C} 9$ & $126.29(9)$ & $\mathrm{O} 1-\mathrm{C} 1-\mathrm{C} 2$ & $126.16(11)$ \\
\hline $\mathrm{C} 14-\mathrm{C} 9-\mathrm{C} 10$ & $121.55(11)$ & $\mathrm{N} 1-\mathrm{C} 1-\mathrm{C} 2$ & $105.95(10)$ \\
\hline $\mathrm{C} 14-\mathrm{C} 9-\mathrm{N} 1$ & $118.68(11)$ & $\mathrm{C} 12-\mathrm{C} 11-\mathrm{C} 10$ & $119.78(14)$ \\
\hline $\mathrm{C} 10-\mathrm{C} 9-\mathrm{N} 1$ & $119.75(10)$ & $\mathrm{C} 12-\mathrm{C} 11-\mathrm{H} 11$ & $122.9(12)$ \\
\hline $\mathrm{C} 13-\mathrm{C} 14-\mathrm{C} 9$ & $118.54(14)$ & $\mathrm{C} 10-\mathrm{C} 11-\mathrm{H} 11$ & $117.3(12)$ \\
\hline $\mathrm{C} 13-\mathrm{C} 14-\mathrm{H} 14$ & $122.6(12)$ & $\mathrm{C} 9-\mathrm{C} 10-\mathrm{C} 11$ & $119.00(12)$ \\
\hline C9-C14-H14 & $118.8(12)$ & $\mathrm{C} 9-\mathrm{C} 10-\mathrm{H} 10$ & $120.5(10)$ \\
\hline $\mathrm{C} 14-\mathrm{C} 13-\mathrm{C} 12$ & $120.52(13)$ & $\mathrm{C} 11-\mathrm{C} 10-\mathrm{H} 10$ & $120.5(11)$ \\
\hline $\mathrm{C} 14-\mathrm{C} 13-\mathrm{H} 13$ & 119.7 & & \\
\hline $\mathrm{C} 4-\mathrm{C} 5-\mathrm{C} 6-\mathrm{C} 7$ & $0.4(2)$ & $\mathrm{N} 1-\mathrm{C} 8-\mathrm{C} 3-\mathrm{C} 2$ & $1.03(13)$ \\
\hline $\mathrm{C} 4-\mathrm{C} 5-\mathrm{C} 6-\mathrm{Cl} 1$ & $-179.26(11)$ & $\mathrm{C} 6-\mathrm{C} 5-\mathrm{C} 4-\mathrm{C} 3$ & $0.2(2)$ \\
\hline $\mathrm{C} 8-\mathrm{C} 7-\mathrm{C} 6-\mathrm{C} 5$ & $-0.69(19)$ & $\mathrm{C} 8-\mathrm{C} 3-\mathrm{C} 4-\mathrm{C} 5$ & $-0.45(19)$ \\
\hline $\mathrm{C} 8-\mathrm{C} 7-\mathrm{C} 6-\mathrm{Cl}$ & $178.95(8)$ & $\mathrm{C} 2-\mathrm{C} 3-\mathrm{C} 4-\mathrm{C} 5$ & $178.98(13)$ \\
\hline $\mathrm{C} 6-\mathrm{C} 7-\mathrm{C} 8-\mathrm{C} 3$ & $0.44(17)$ & $\mathrm{C} 4-\mathrm{C} 3-\mathrm{C} 2-\mathrm{O} 2$ & $1.2(2)$ \\
\hline $\mathrm{C} 6-\mathrm{C} 7-\mathrm{C} 8-\mathrm{N} 1$ & $179.89(11)$ & $\mathrm{C} 8-\mathrm{C} 3-\mathrm{C} 2-\mathrm{O} 2$ & $-179.36(14)$ \\
\hline $\mathrm{C} 7-\mathrm{C} 8-\mathrm{N} 1-\mathrm{C} 1$ & $178.11(11)$ & $\mathrm{C} 4-\mathrm{C} 3-\mathrm{C} 2-\mathrm{C} 1$ & $-178.96(13)$ \\
\hline $\mathrm{C} 3-\mathrm{C} 8-\mathrm{N} 1-\mathrm{C} 1$ & $-2.38(13)$ & $\mathrm{C} 8-\mathrm{C} 3-\mathrm{C} 2-\mathrm{C} 1$ & $0.52(13)$ \\
\hline $\mathrm{C} 7-\mathrm{C} 8-\mathrm{N} 1-\mathrm{C} 9$ & $0.14(18)$ & $\mathrm{C} 8-\mathrm{N} 1-\mathrm{C} 1-\mathrm{O} 1$ & $-176.24(13)$ \\
\hline $\mathrm{C} 3-\mathrm{C} 8-\mathrm{N} 1-\mathrm{C} 9$ & $179.64(11)$ & $\mathrm{C} 9-\mathrm{N} 1-\mathrm{C} 1-\mathrm{O} 1$ & $1.80(19)$ \\
\hline $\mathrm{C} 1-\mathrm{N} 1-\mathrm{C} 9-\mathrm{C} 14$ & $52.94(16)$ & $\mathrm{C} 8-\mathrm{N} 1-\mathrm{C} 1-\mathrm{C} 2$ & $2.58(12)$ \\
\hline $\mathrm{C} 8-\mathrm{N} 1-\mathrm{C} 9-\mathrm{C} 14$ & $-129.33(12)$ & $\mathrm{C} 9-\mathrm{N} 1-\mathrm{C} 1-\mathrm{C} 2$ & $-179.37(10)$ \\
\hline $\mathrm{C} 1-\mathrm{N} 1-\mathrm{C} 9-\mathrm{C} 10$ & $-125.42(12)$ & $\mathrm{O} 2-\mathrm{C} 2-\mathrm{C} 1-\mathrm{O} 1$ & $-3.1(2)$ \\
\hline $\mathrm{C} 8-\mathrm{N} 1-\mathrm{C} 9-\mathrm{C} 10$ & $52.31(16)$ & $\mathrm{C} 3-\mathrm{C} 2-\mathrm{C} 1-\mathrm{O} 1$ & $176.95(12)$ \\
\hline $\mathrm{C} 10-\mathrm{C} 9-\mathrm{C} 14-\mathrm{C} 13$ & $0.92(19)$ & $\mathrm{O} 2-\mathrm{C} 2-\mathrm{C} 1-\mathrm{N} 1$ & $178.00(12)$ \\
\hline $\mathrm{N} 1-\mathrm{C} 9-\mathrm{C} 14-\mathrm{C} 13$ & $-177.41(11)$ & $\mathrm{C} 3-\mathrm{C} 2-\mathrm{C} 1-\mathrm{N} 1$ & $-1.90(12)$ \\
\hline $\mathrm{C} 9-\mathrm{C} 14-\mathrm{C} 13-\mathrm{C} 12$ & $-0.4(2)$ & $\mathrm{C} 13-\mathrm{C} 12-\mathrm{C} 11-\mathrm{C} 10$ & $0.8(2)$ \\
\hline $\mathrm{C} 14-\mathrm{C} 13-\mathrm{C} 12-\mathrm{C} 11$ & $-0.4(2)$ & $\mathrm{C} 14-\mathrm{C} 9-\mathrm{C} 10-\mathrm{C} 11$ & $-0.56(18)$ \\
\hline $\mathrm{C} 7-\mathrm{C} 8-\mathrm{C} 3-\mathrm{C} 4$ & $0.11(18)$ & $\mathrm{N} 1-\mathrm{C} 9-\mathrm{C} 10-\mathrm{C} 11$ & $177.75(11)$ \\
\hline $\mathrm{N} 1-\mathrm{C} 8-\mathrm{C} 3-\mathrm{C} 4$ & $-179.42(11)$ & $\mathrm{C} 12-\mathrm{C} 11-\mathrm{C} 10-\mathrm{C} 9$ & $-0.30(19)$ \\
\hline $\mathrm{C} 7-\mathrm{C} 8-\mathrm{C} 3-\mathrm{C} 2$ & $-179.43(10)$ & & \\
\hline
\end{tabular}

Hydrogen-bond geometry $\left(A,{ }^{\circ}\right)$

\begin{tabular}{lllll}
\hline$D-\mathrm{H} \cdots A$ & $D-\mathrm{H}$ & $\mathrm{H} \cdots A$ & $D \cdots A$ & $D-\mathrm{H} \cdots A$ \\
\hline $\mathrm{C} 10-\mathrm{H} 10 \cdots \mathrm{O} 1^{\mathrm{i}}$ & $0.956(17)$ & $2.572(18)$ & $3.2063(16)$ & $124.0(13)$ \\
\hline
\end{tabular}

Symmetry code: (i) $x+1, y, z$. 